\title{
اتجاه ابن خالويه النحوي وموقفه من الأصول في كتاب \\ إعراب ثلاثين سورة من القرآن الكريد.
}

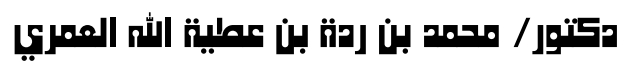

جامعة أم القرى - الكلية الجامعية بالقتفذة

\section{ملخص البحث: - 2 - 20}

حظي النحو العربي بعناية ملموسة من قبل الباحثني، فتتاوله بعضهم بدر اسة شاملة لآر اء بعض النحويين، أو بدر اسة لمسائله، وفريق آخر تتاوله من خلال مدرسة معينة، بله

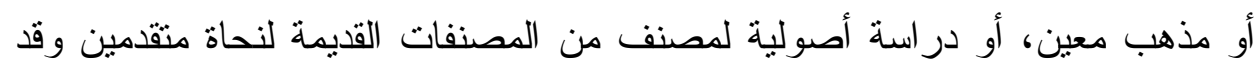
وجدت من الضروري در اسة منهج ابن خالويه وموقفه من الأصول، في كتابه 》إعر اب دابه ثلاثين سورة من القرآن الكريمه لأهمية تسليط الضوء عليه بوصفه أحد أهم أعلام

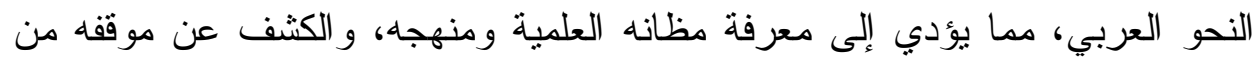

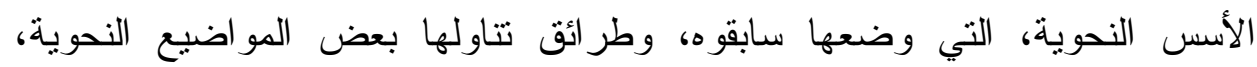
بالاستناد إلى تللك المعارف أو الهن وضعاده عنها. 
مما لا شك فيه أن النحو العربي من أجلِّ العلوم مكانة و أجودهـا نَفْعًا، إذ بهـ يستقيم اللسان، ويعلو المرء في البيان، وبهذا العلم يصان كتاب الله، وتصان سنة نبيه محمد

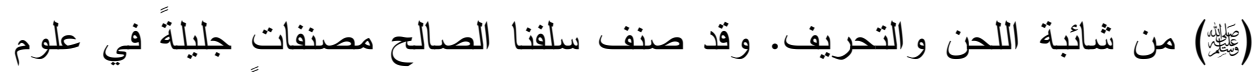
العربية عموماً وفي النحو خصوصاً، وكانوا يتنافسون في أن يكون لكل قطر مذهب وفي

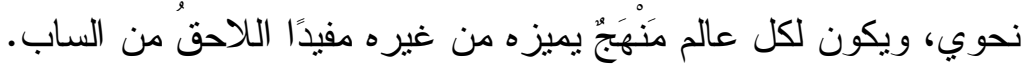
ثانياً: هدف البحث: ونكون

يهدف البحث إلى دراسة منهج ابن خالويه النحوي، للكثف عن آرائه النحوية ومدى قربها أو بعدها من المدارس النحوية في كتابه 》إعر اب ثلاثثن سورة من القر آن الكريم«، إضافةً إلى محاولة الربط بين فكر ابن خالويه النحوي اللغوي القر آني، و علوم المتقدمين في معاني القرآن وإعرابه، من خلال الكثف عن موقفه من الأصول النحوية. ثالثاً: منهج البحث: أما المنهج الذي اتبعته في الدراسة فهو المنهج الوصفي التحليلي، الذي يمكنني من استقر اء المادة النحوية في كتاب ابن خالويه، لمعرفة مكانتها بين أر اء النحويين القدماء، و ون ثم تحليل تلك المادة، لاستبيان ملامحها، ومعرفة المشترك بينها الذي يشكل ظاهرة و اضحة ثابتة في فكر ابن خالويه النحوي، ونركيب النتائج بما يقرب المعلومات، ويصل بنا إلى الإضاءة على معالم المعارف النحوية لديه. رابعاً: ابن خالويه(') ومكانته في النحو العربي:

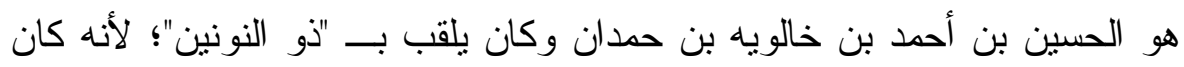

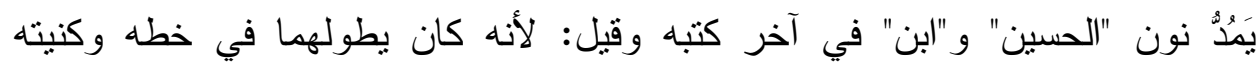
أبو عبداله الهمذاني النحوي

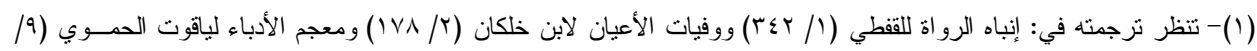

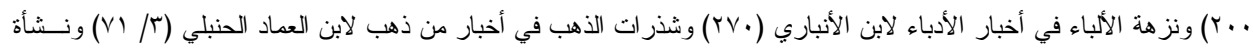

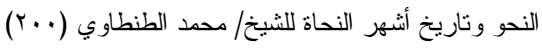


ولد في "هذان" ونشأ فيها، وهي المدينة المعروفة من بلاد الجبال ببلاد فارس، ثم

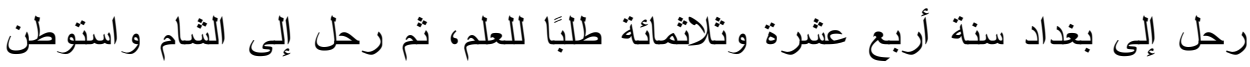
حلب، وتصدر بها وبميَّا فَارقِين وحمص للإفادة و التدريس والفتوى و التصني وقد وند

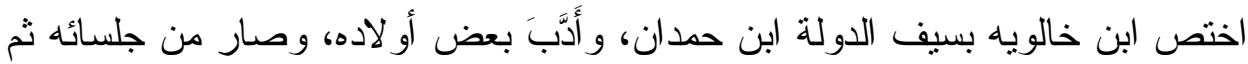
عاش بعد ذللك في صحبة شريف ولد سيف الدولة، وغيره من آل حمدان يكرمونه، ويدرسون عليه، ويقتبسون من علمه إلى أن نوفاه الله

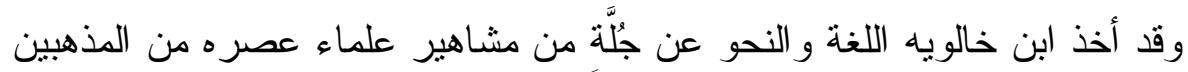

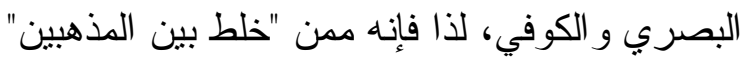
ومن هؤلاء الثيوخ:

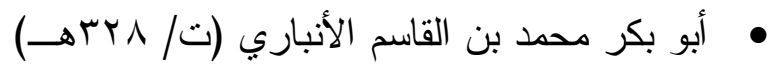

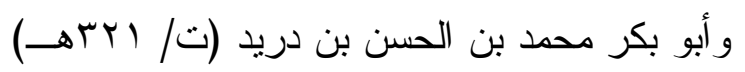

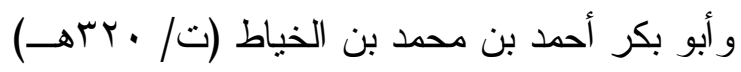

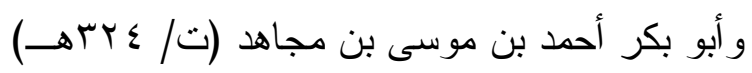

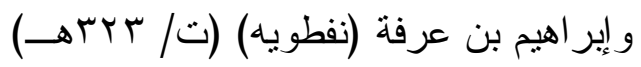

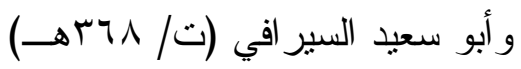

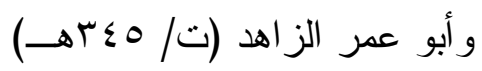

و هذا الأخير أكثر من النقل عنه بعبار ات مختلفة

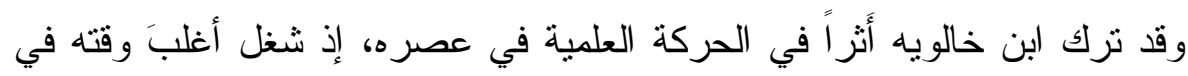
التأليف و المطالعة، فكثير من مصنفاته يغلب عليها طابع التتبع و الاستقر اء وقد أخذ عنه عدد غير قليل، وتميزوا بالسماع منه ونه

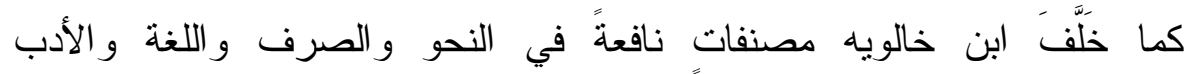

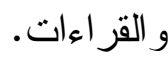

خامساً: كتاب (إعراب ثلاثين سورة من القرآن الكريم):

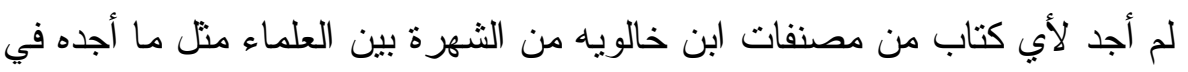

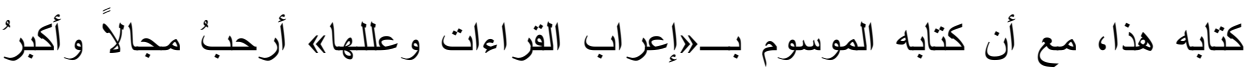

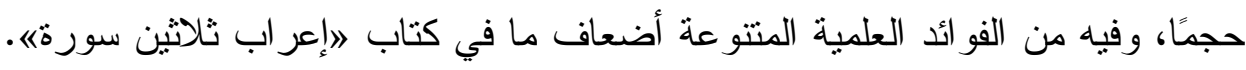


و هذا الكتاب الذي صنفه ابن خالويه أعرب فيه ثلاثين سورة بدءاً من سورة الفاتحة [أُمِّ القرآن] ثم انتقل بعد ذلك ليبدأ بإعر اب سور من [جزء عم] من أول سورة الطارق إلى ألى

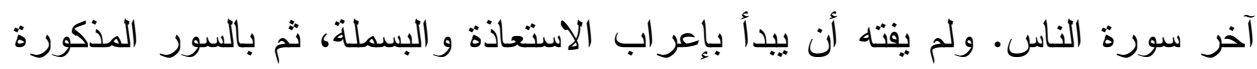

و أفصح عما أر اده من تأليف هذا المصنَّف بقوله: إقال أبو عبداله الحسين بن أحمد بن خالويه النحوي: هذا كتابُ ذكرتُ فيه إعراب ثلاثين سورة من المفصل بثرح

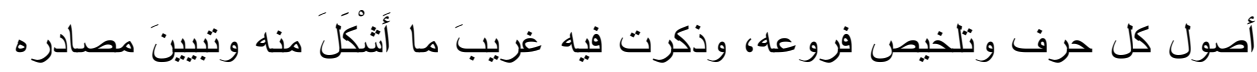
وتثتيتَه وجمعَه؛ ليكون معونةً على جميع ما برد عليك من إعراب القر آن - إن شاء الله - وما توفيقي إلا باله عليه توكلت وهو رب العرش العظيمه. وقد سار ابن خالويه في عرضه السور التي تتاولها على طريقة واحدة من أوله

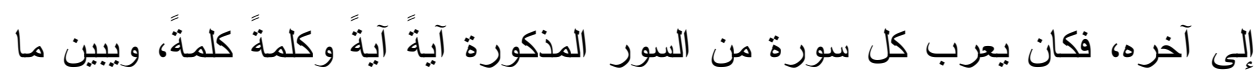
فيها من معان لغوية. وقلما يتعرض لما فيها من خلاف نحوي من دون تفصيل أو إبداء رأي أو اعتر اض على رأي أو اختيار رأي ما، اللهم في النزر اليسير، و إذا كان في وني

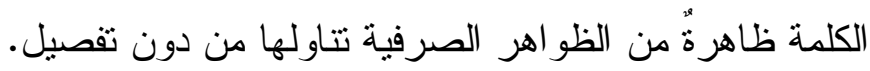
سادساً: اتجاهه النحوي:

كان ابن خالويه - رحمه الله تعالى -_- من النحويين ذوي الثقافة العالية، وخيرُ دليل على ذلك كثرةٌ مصنفاته، وتتوعُها في مختلف العلوم، ولعل هذا التتوع قد كَوَّنَ شخصيةً علميةً لدى ابن خالويه بين النحاة المتأخرين، تمتاز بالحَيدَة و الموضو عية. وتحديد اتجاه النحوي إنما يقوم على استقر اء آرائه وتتبعها، و المصطلحات التي يستخدمها، وكذا العبار ات التي يتتاولها كأن يقول مثنا: "قال به بعض أصحابنا" أو "قال

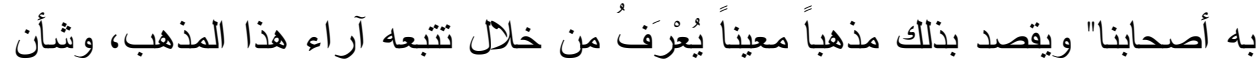
ابن خالويه في ذللك شأن كثير من النحويين. 
و إن الناظر المتأمل في آر اء ابن خالويه ليجده يميل في بعض آرائه للكوفيين وفي

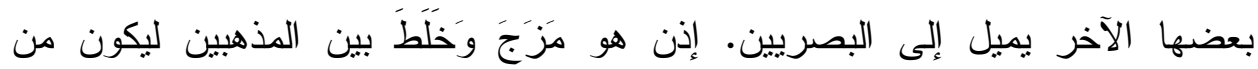

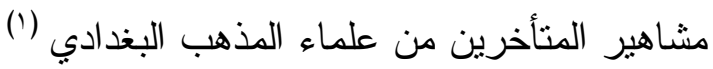

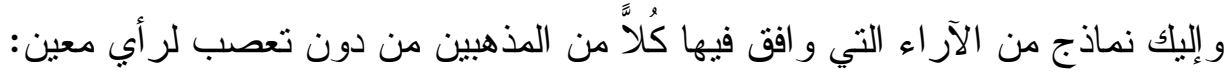
أ- من الآراء التي وافق فيها البصريين:

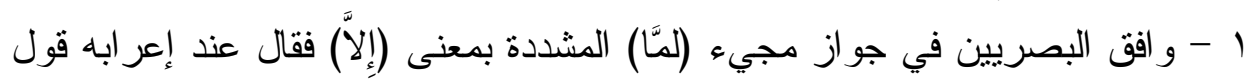

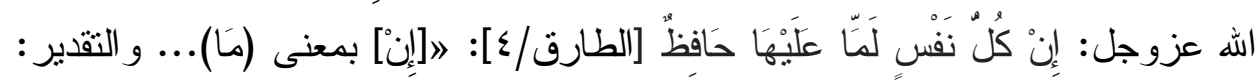

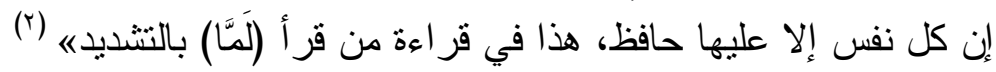

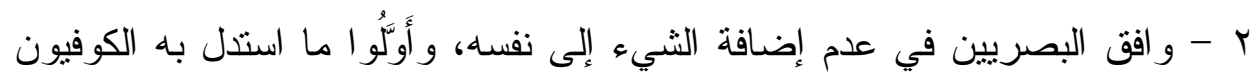
على حذف مضاف (r)

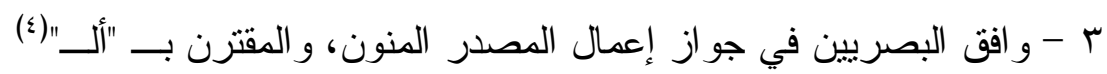
ب- من الآراء التي وافق فيها الكوفينين:

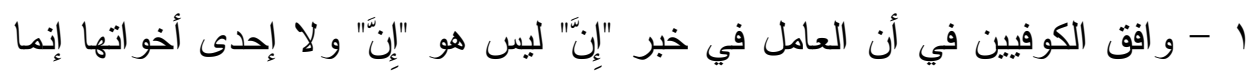

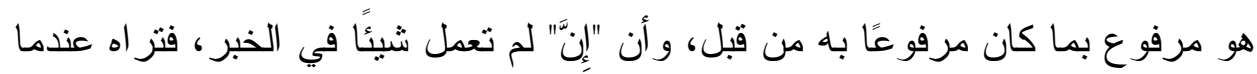

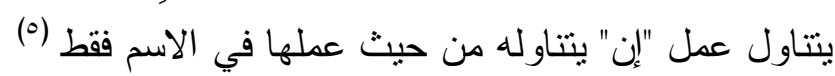

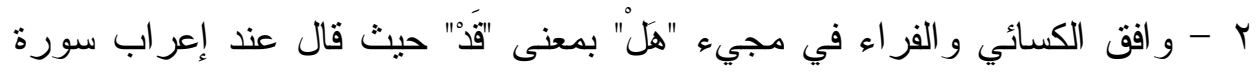

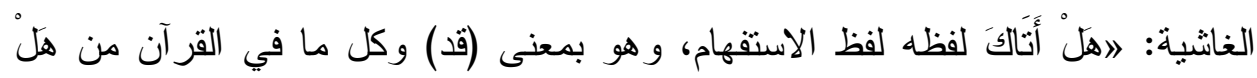

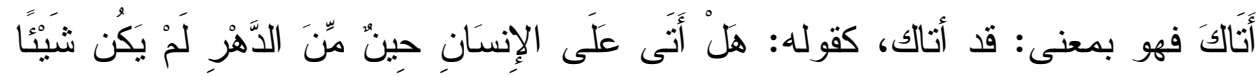

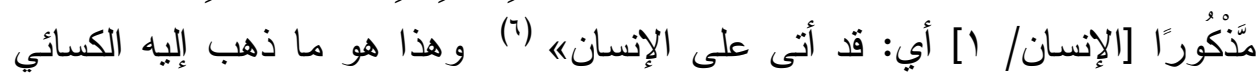
و الفراء. 
r - اختار مذهب الكوفيين في أن فعل الأمر معرب مجزوم بلام مقدرة، بدليل ذكره

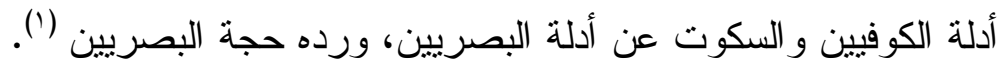
وو افق البصريين والكوفيين في ناصب الفعل المضارع بعد "حتى" فتارة يقول إنه منصوب بــ "حتى" نفسها، وتارة يقول منصوب بإضمار (أن).

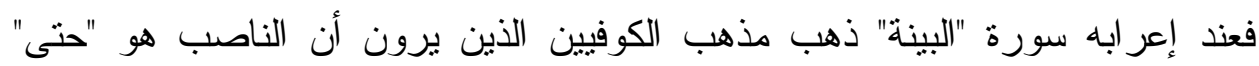

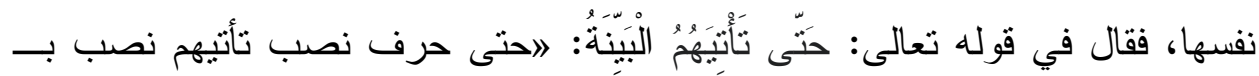
حتى (r) و عند إعر ابه سورة "التكاثر" ذهب مذهب البصريين الذين برون أن الناصب ليس حتى آنى

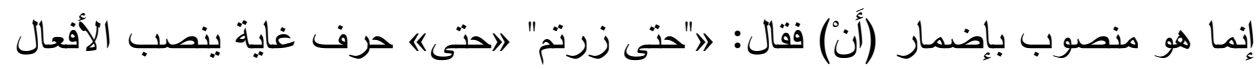

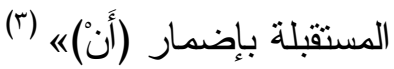
فمن خلال هذه النماذج يتبين لنا أن ابن خالويه بغداديٌٌ المذهب، و الدليل على ذلك

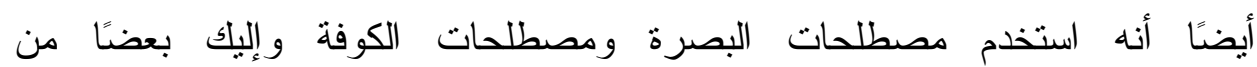
المصطلحات التي استخدمها ابن خالويه. 1 - مصطلح الصفة عند البصريين يقابله عند الكوفيين (النعت): فنرى ابن خالويه استخدم المصطلحين (مصطلح النعت) جاء في كتابه (إعر اب ثلاثين

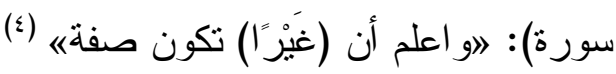

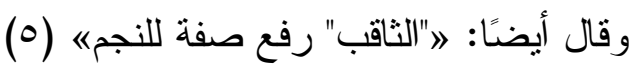
وقال: 》"المستقيم": نصب نعت للصر اطه (7)

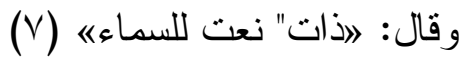


r - مصطلح (الجر) عند البصريين يقابله (الخفض) عند الكوفيين: و استخدم ابن خالويه المصطلحين:

قال عن الجر : "ايوم الدين": [يوم] جر بالإضافةه (1) (1)

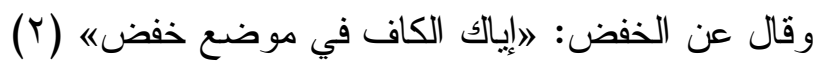

r - مصطلح (الضمبر) عند البصريين يقابله مصطلح (المكني) عند الكوفيين: و استخدم ابن خالويه مصطلح المكني، أو الكناية في كتابه (إعراب ثلاثين سورة) ولم يستخدم مصطلح الضمير؛ لأن الضمير فيه معنى الخفاء والاستتار، فأطلق عليه الكوفيون اسم "المكني، أو الكناية"؛ لأنه يرمز به عن الظاهر اختصارًا، وهذه التسمية

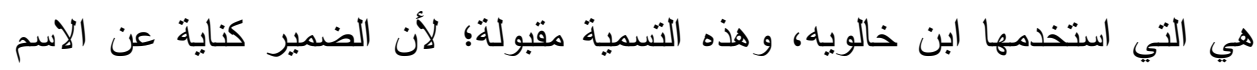
الظاهر . - مان

قال ابن خالويه: "عليهم"على" حرف جر ، وتكتب بالياء؛ لأن ألفها تصير مع المكني ياء، نحو: (عليك) ..... وهي مع المظهر ألفه (ب).

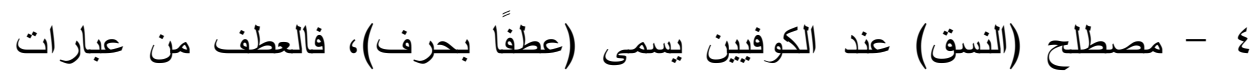
البصريين، و النسق من عبار ات الكوفيين.

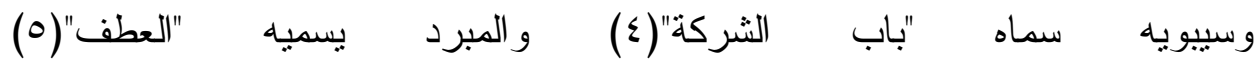

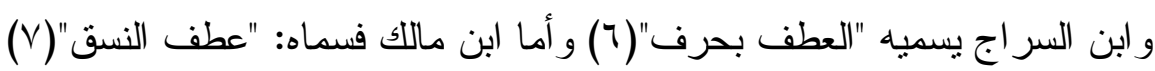

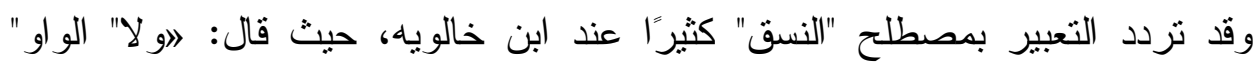

حرف نسق (^) 0 - مصطلح (الجدد) عند الكوفيين، يقابله مصطلح "النفي" عند البصريين:

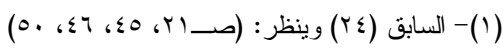

$$
\begin{aligned}
& \text { (YT) }
\end{aligned}
$$

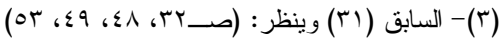

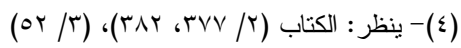

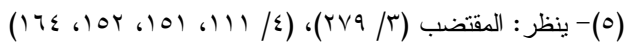

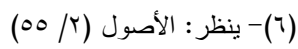

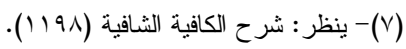

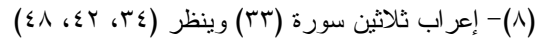


وقد ورد مصطلح "الجحد" عند ابن خالويه كثيرًا. ومن النعبير عنه بــ "الجحد" قوله

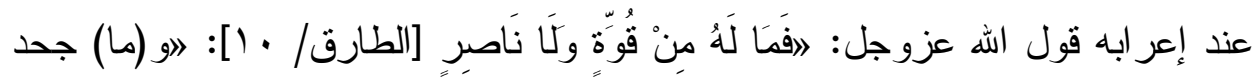

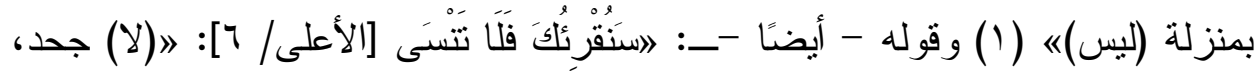

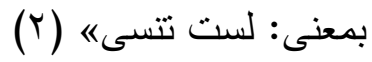
7 - مصطلح (الصلة) عند الكوفيين يقابله مصطلح (الزيادة) عند البصريين: وقد استخدم ابن خالويه المصطلحين، قال عند إعرابه قوله تعالى: · ورلا الضالين)

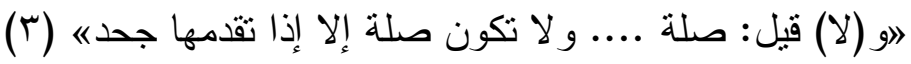

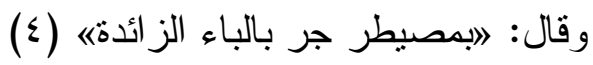

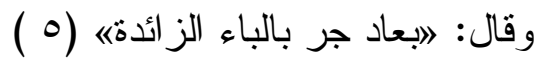

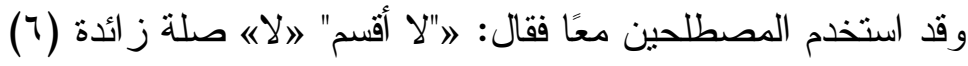
- V مصطلح "الإضمار" بمعنى "الحذف، أو الثيء المقدر" وقد استعمل هذا المصطلح

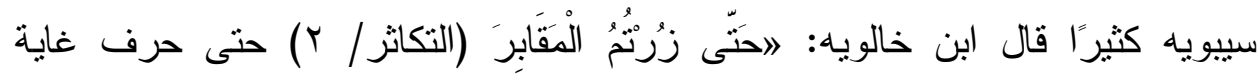
ينصب الأفعال المستقبلة بإضمار (أن) ويخفض الأسماء بإضمار (إلى)ه (V)

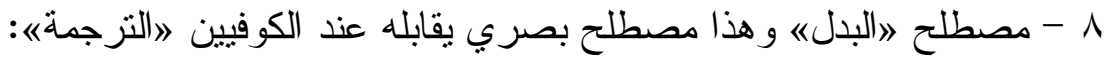
وقد استخدم ابن خالويه مصطلح "البدل" حيث قال: الاوالعرب تبدل النكرة من النكرة،

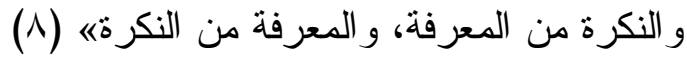

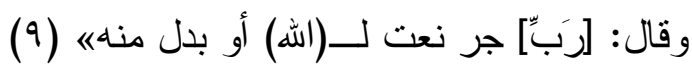
ولم يستخدم ابن خالويه مصطلح "التزجمة"( ) أو "التكرير" الترب

\footnotetext{
(1) (Y) السابق (OY)

( السابق (r)

(Y)

( (

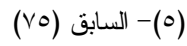

( ( ال) السابق

( ) السابق (T)

( )

(9) السابق (r)
} 
9 - مصطلح 》الحال) مصطلح بصري، يقابله عند الكوفيين 》القطع):

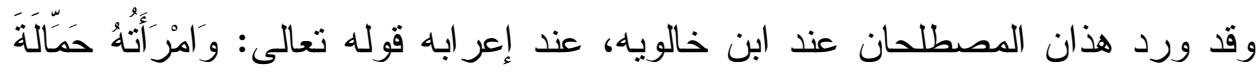

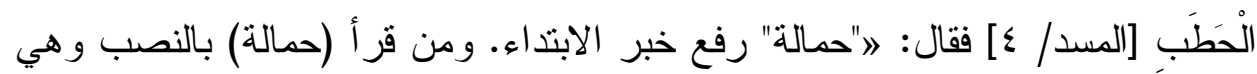

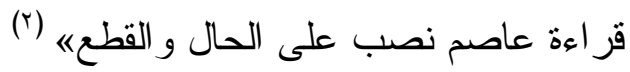
سابعاً: موقف ابن خالويه من الأصول النحوية: أصول النحو هي أدلته التي تفرعت منها فروس الاصول فروعه وفصوله، كما أن أصول الفقه هي أدلة الفقه التي تتوعت عنها جملته وتقصيله. و أصول النحو هي: السماع، و القياس، و الإجماع، واستصحاب الحال. ويجدر بالبحث أن بيين موقف ابن خالويه من هذه وله الأصول النحوية لكن لما كان كتاب ابن خالويه الموسوم بـ "إعراب ثلاثثين سورة" مقصورًا على الإعراب ولم يتناول الخلاف النحوي إلا في النزر اليسير اقتصر فيه

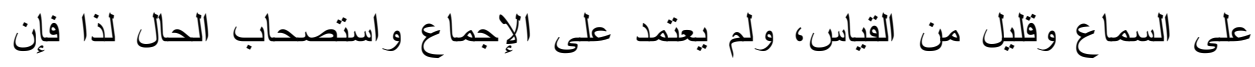

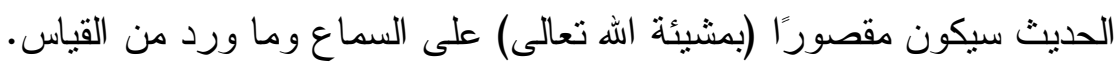

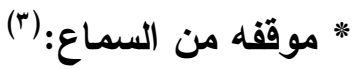
من المعلوم الذي لا يقبل جدالاً، أو مناقشة أن السماع هو عماد القاعدة النحوية

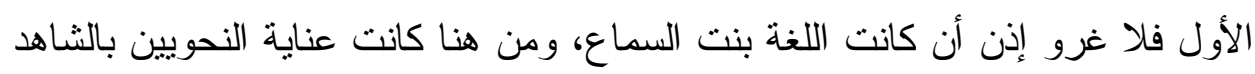

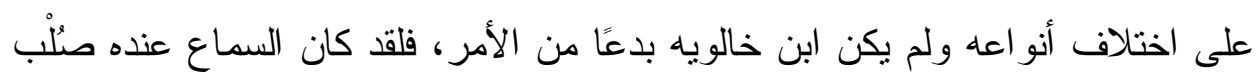

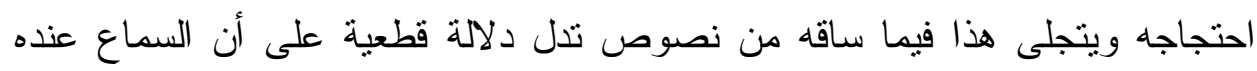

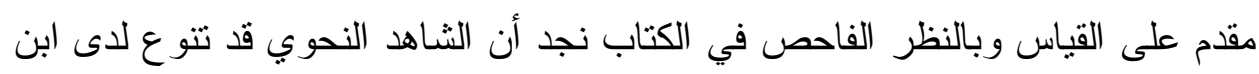
خالويه على النحو الآتي: ملىم وبلى

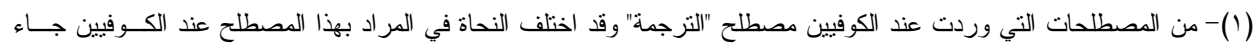

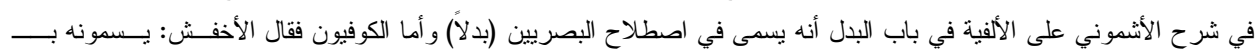

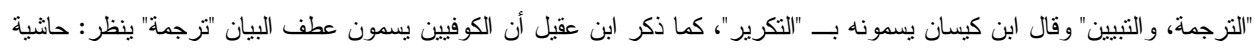

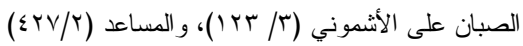

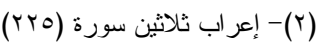

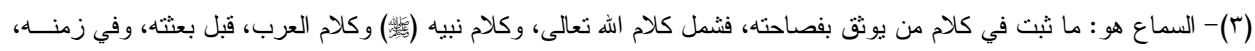

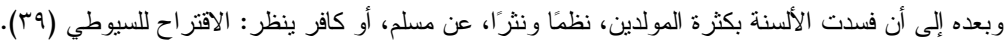


أ - الشاهد القر آني وقر اع|ته:

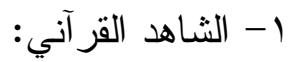

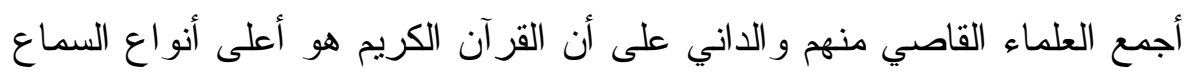

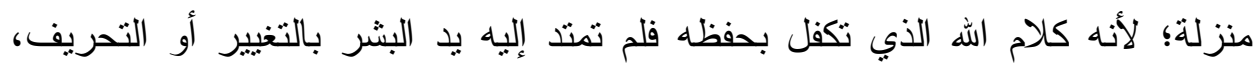

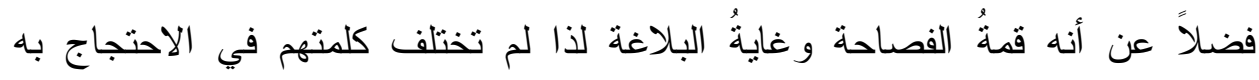
وبقر اءاته في العربية

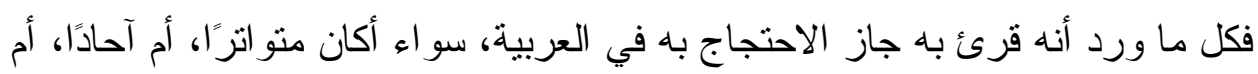
شاذا، وقد أطبق الناس على الاحتجاج بالقر اءات الثاذة في العربية إذا لم تخالف قياسًا. وقد تتوع الاستشهاد بالقر آن الكريم على النحو الآتي: الاستشهاد به على صحة القاعدة وثبوتها:

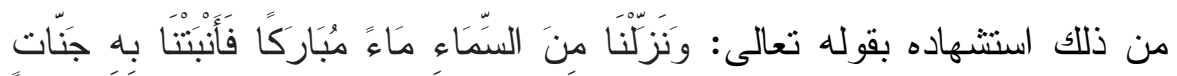

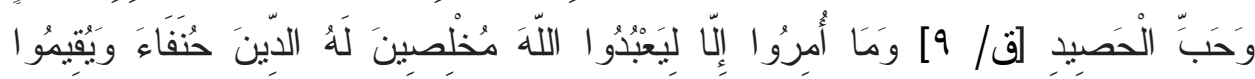

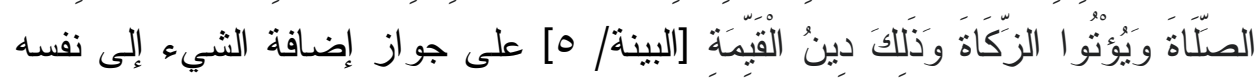
عند الكوفيين (1)

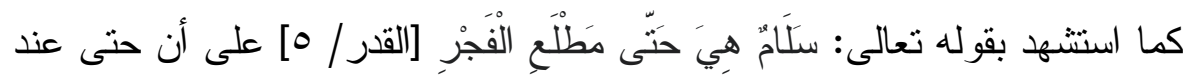
بعض الكوفيين ليست هي الجارة و إنما نابت عن (إلى) فقال: ا"مطلع" جر بحتى و إنما

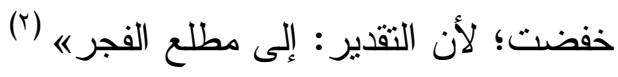

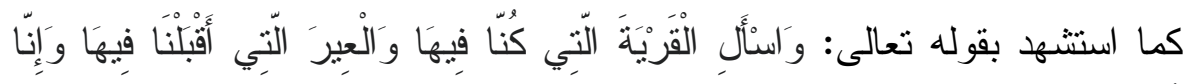
لَصَادقُونَ [يوسف/Ar] r على جواز حذف المضاف و إقامة المضاف إليه مقامه، حيث

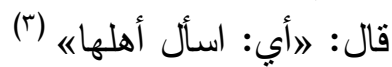

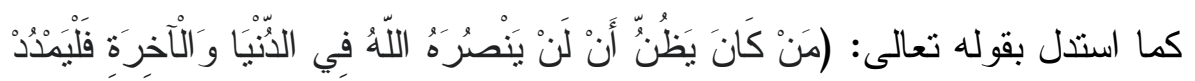

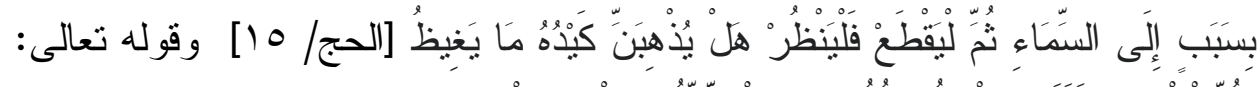

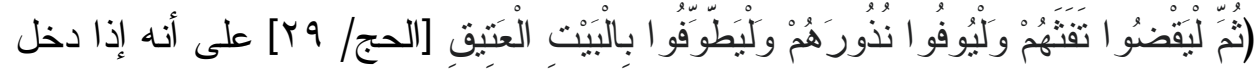

(1) ينظر : إعراب ثلاثين سورة (179)

(r) (I I IV ( السابق (T) 
الحرف (ثم، أو الواو، أو الفاء) على لام الأمر يجوز إسكانها والأصل فيها الكسر،

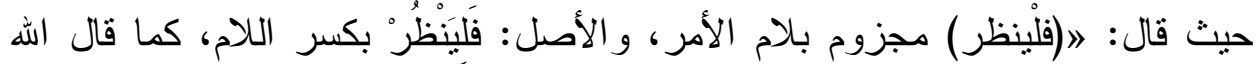

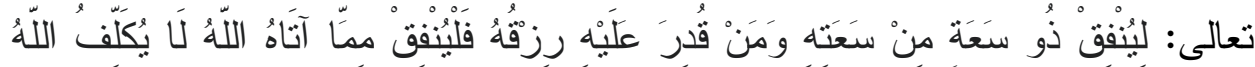

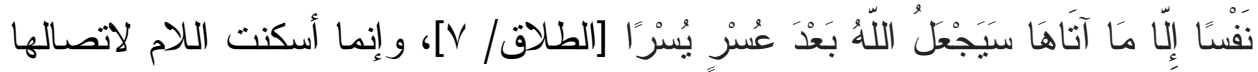

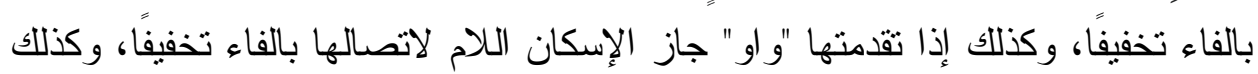

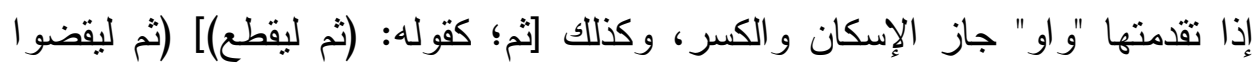

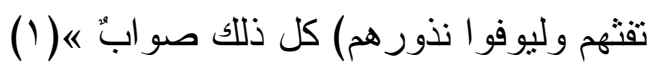

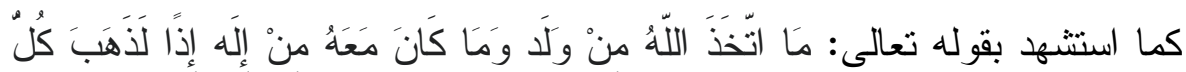

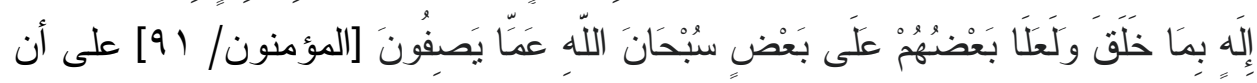

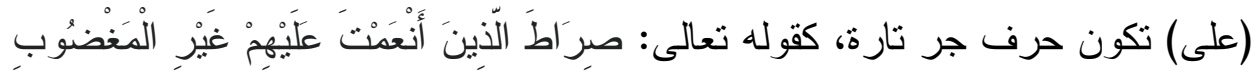

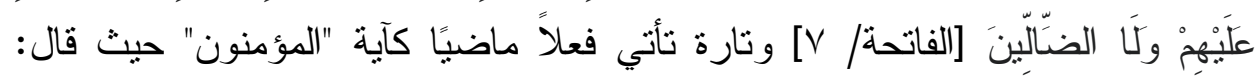
״(على) حرف جر، وتكتب بالياء؛ لأن ألفها تصير مع المكني ياء، نحو: (عليك،

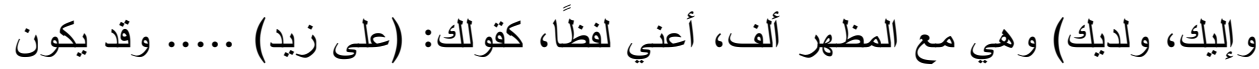

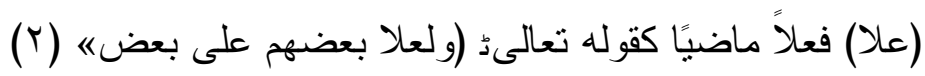

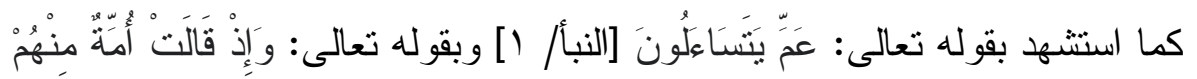

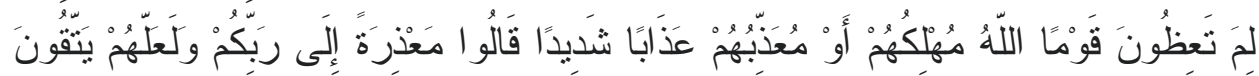

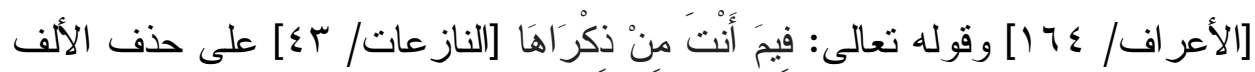

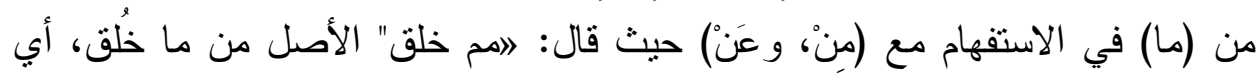
من أي شيء خُلق؛ فأدغمت النون في الميم. وحذفت الألف من الهاهي في الاستفهام مع من وعن، كقوله: (عم يتساءلون) ومع اللام كقوله: (لم تعظون) ومع في كقوله: (فيم

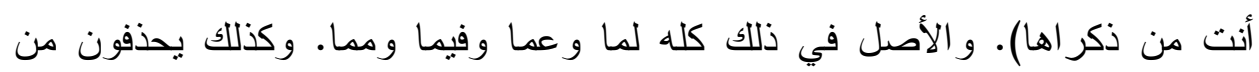

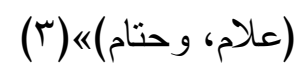




$$
\text { وقد يأني به لإيضاح معنى لغوي: }
$$

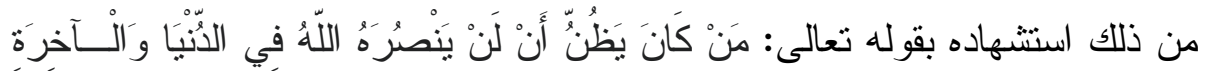

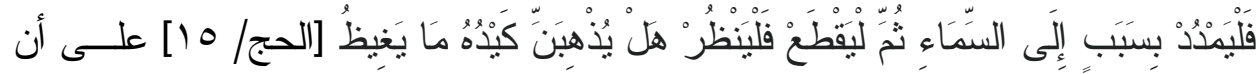

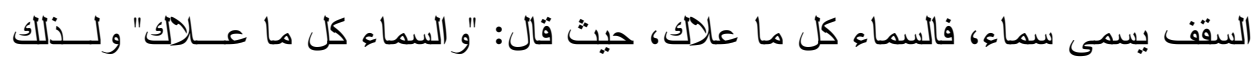

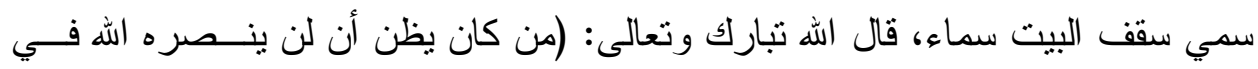

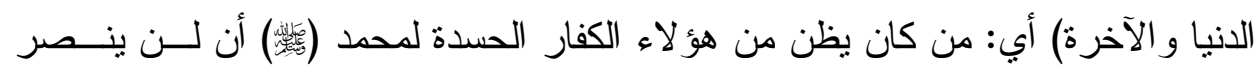

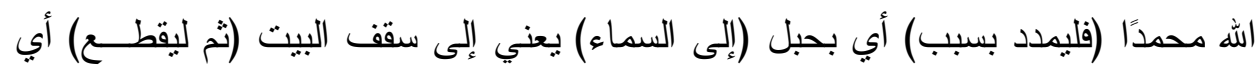
يختق. أبي: يختنقه (1)

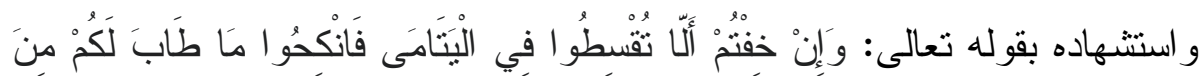

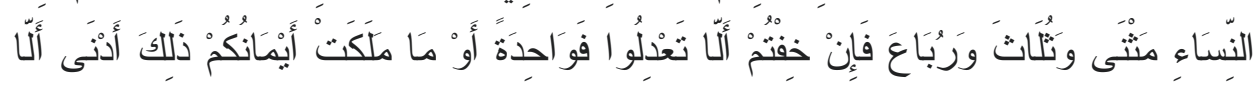

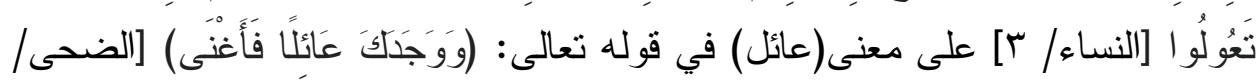

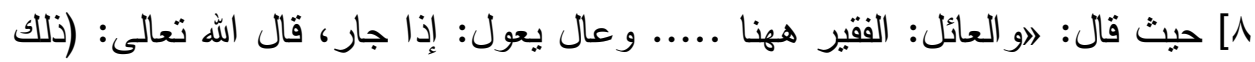

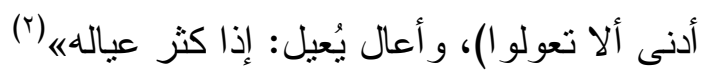

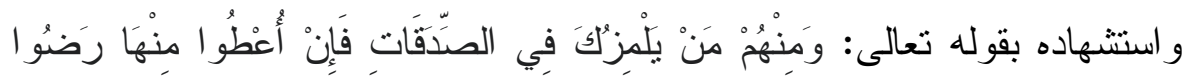

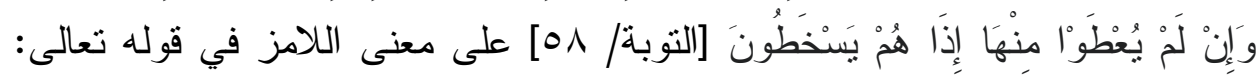

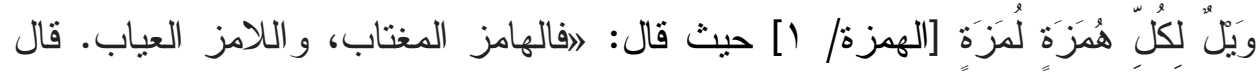

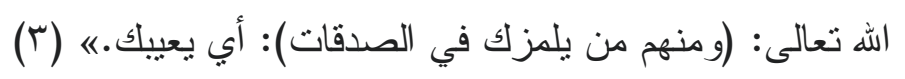
وقد يأتي بـ لمشتقات الكلمة:

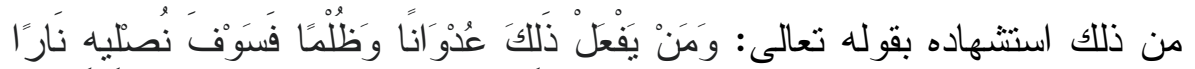

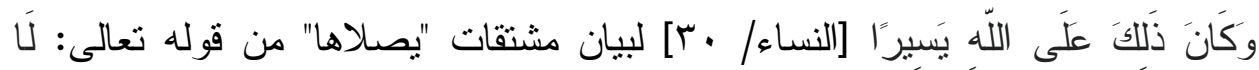

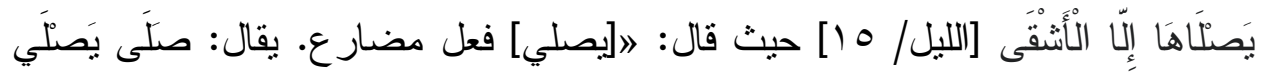




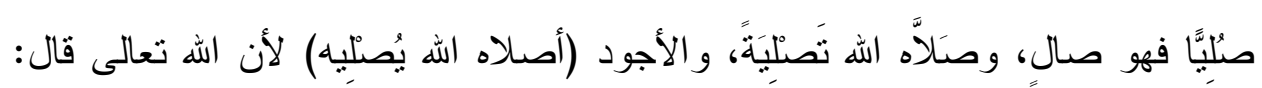
(فسوف نُصليه نارًا)

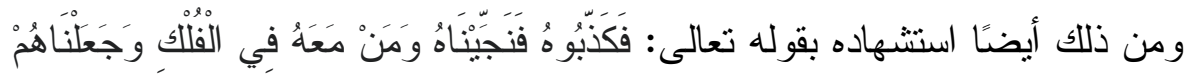

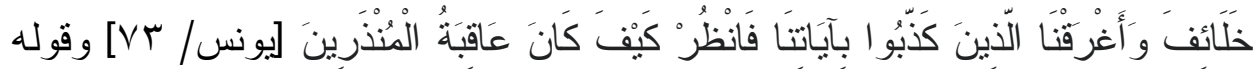

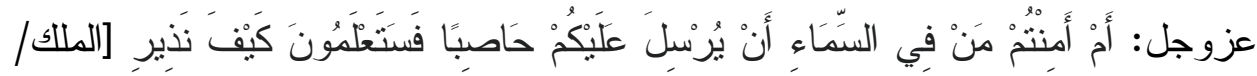

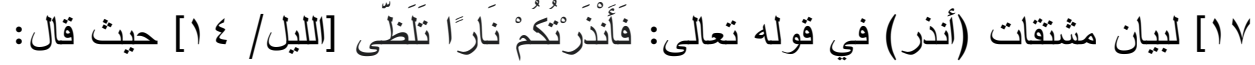

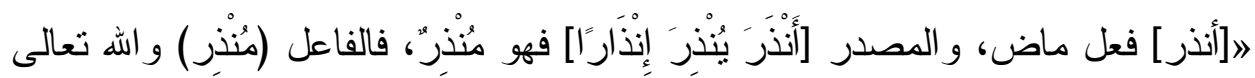

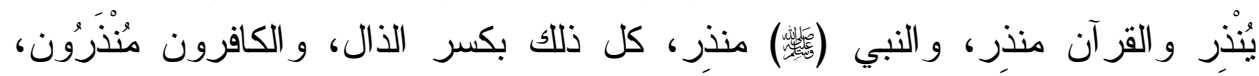
(فانظر كيف عاقبة المنذرين) هذا بفتح الذال لا غير • وقد يكون النذير مصدرًا بمعنى الإنذار، كقوله تعالى: (فكيف كان نذير) (فكيف كان نكير). يريد تعالى إنذاري و إنكاري.

القراعات القزراء آنية:

استذل ابن خالويه بالقراءات القرآنية -أيضًا- واحتج بها في تثبيت القاعدة،

$$
\text { وترسيخ الحكم }
$$

من ذلك قر اءة الحسن ورؤبة: (الحمد)(r) بكسر الدال، بناء على أنها حركة إتباع لكسرة

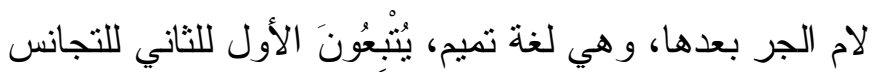

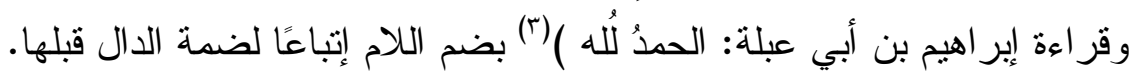

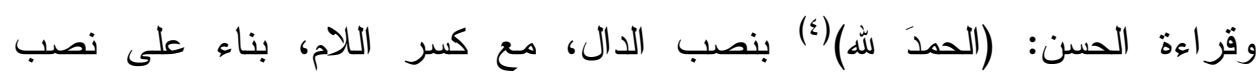

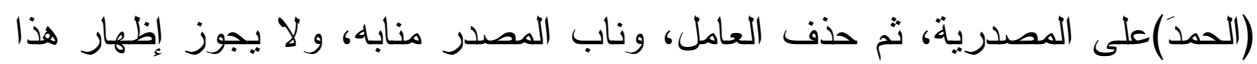
الناصب؛ لئلا يجمع بين البدل و المبدل منـه.

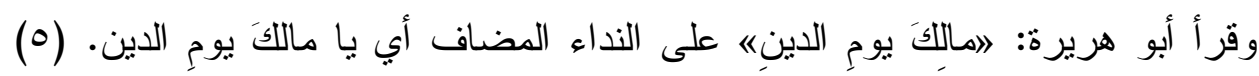
بنصب (مالك) بناء على أنه منادى حذفت منه أداة النداء جو ازًا. 


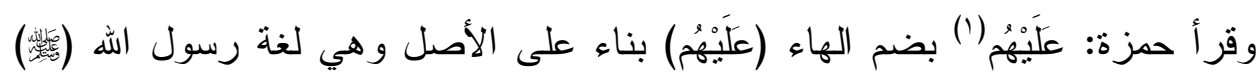

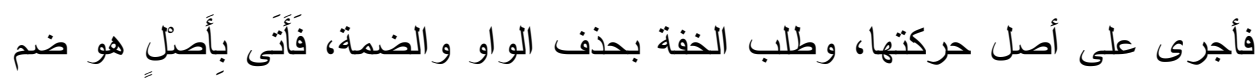

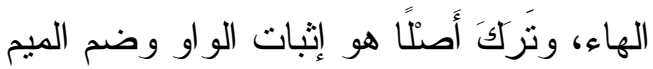

وقرأ يعقوب: "فبذلك فلتفرحوا" (r) بالتاء على أصل الأمر ، حيث دخلت اللام على فعل

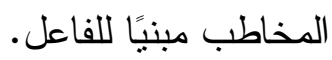
وقر أ المفضل عن عاصم: 》ما هن أمهاتهمه (؟) برفع (أمهاتهم) بإهمال (ما) على لغة وهناك مبحث خاص بالقر اءات القر آنية وتوجيهها.

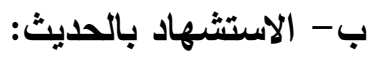

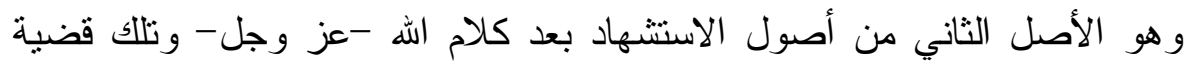
(أعني قضية الاستشهاد بالحديث النبوي الثريف) قضية ثار حولها جدل كبير بين النحويين.

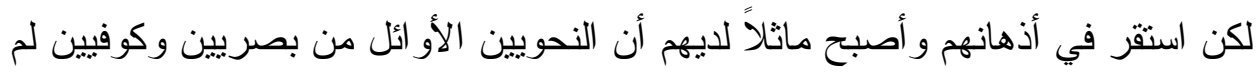

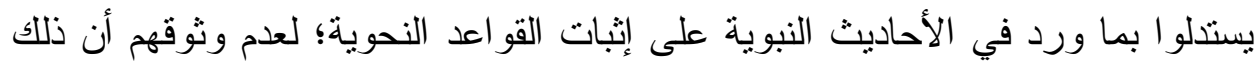

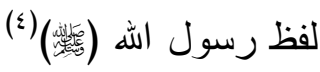
لكن هذا الحكم ليس بصحيح فإن سيويه يعد أول من احتج بالحديث النبوي

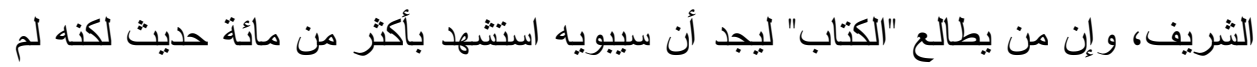

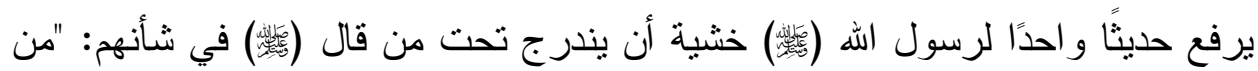

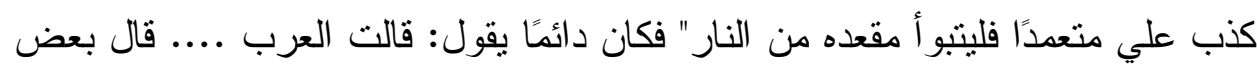
العرب، ثم يذكر الحديث، بل إن ابن الضائع نفسه استشهـ بأحاديث كثيرة في كتابه

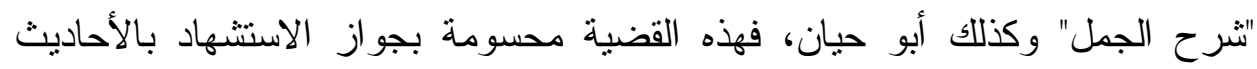
النبوية الثريفة وقد استثهد ابن خالويه بالأحاديث النبوية الثريفة

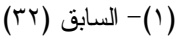

(r)

(Y)

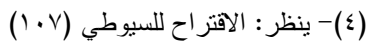




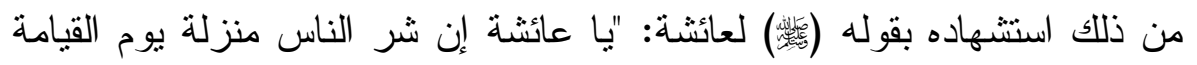

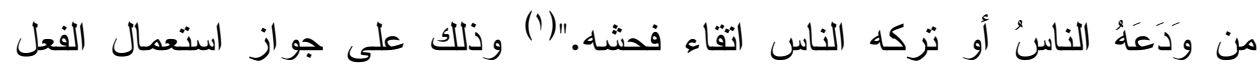
الماضي من (يدع)، فقال: "ودعه".

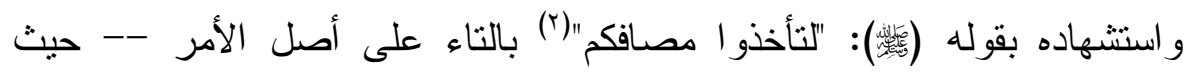
دخلت اللام على فعل المخاطب مبنيًا للفاعل. ج- الاستشهاد بأقوال العرب:

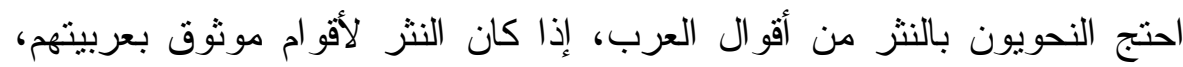

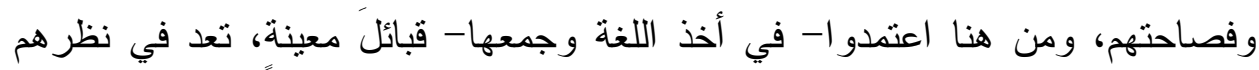
القبائلَ التي تمنل الفصاحةَ و العربيةً السليمة وكذلك لم يخفل ابن خالويه الاستشهاد بأقو ال العرب، وما أُثِرَ في مخاطباتهم

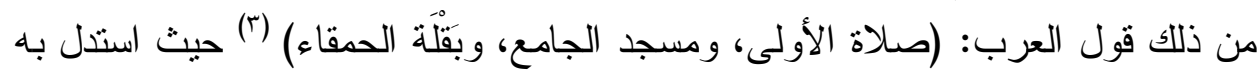

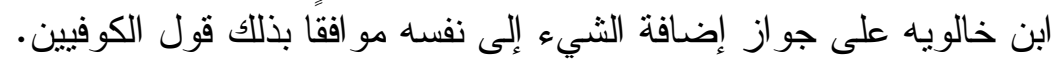

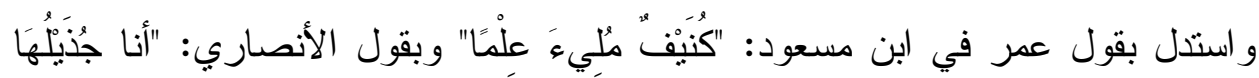

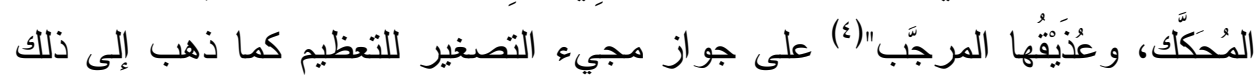
الكوفيون.

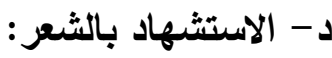

لاقى الثعر اهتمامًا كبيرًا من اللغويين، فانضم إلى الثاهد القرآني بوصفه دعامة أساسية لأي قضية نحوية أو لغوية ير اد الاستدلال عليها. ومن هنا جاء اهتمام ابن خالويه بالثاهد الثعري، فقد حشد في كتابه (إعراب ثلاثثن سورة) كثيرًا من الثو اهد الشعرية بدت فيها بعض الظو اهر و السمات التي توضح مدى اهى

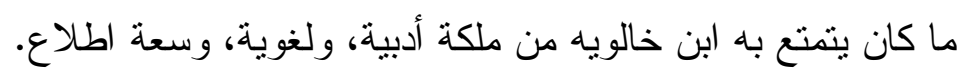

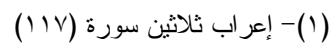

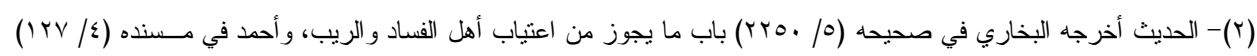

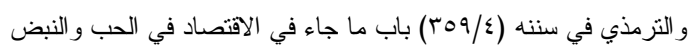

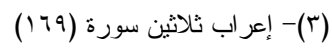

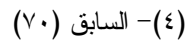


ومن ذللك ما استدل به على جواز حذف لام الأمر من المضارع إذا كان للغائب في قول الثاعر:

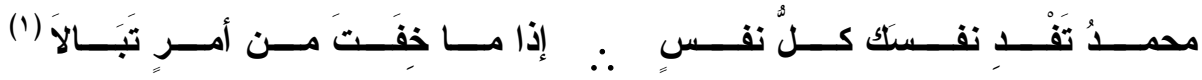
أر اد : لَتَفْ، محذَف و استدل على أن (لا) لا تكون صلة إلا إذا تقدمها جحد بقول الثاعر :

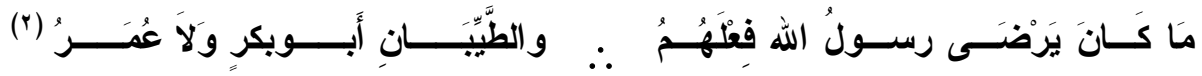
و واستدل على مجيء الفعل الماضي (يدع) بقول الثَاعر :

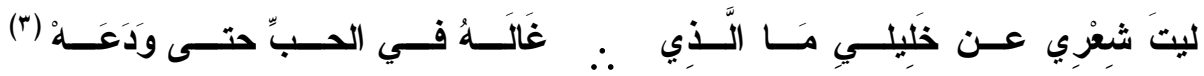
و استدل على أن من جعل "سماء" جمعًا فو احده (سماءة، وسماوة) بقول العجاج:

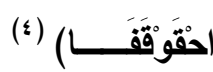

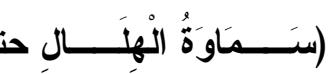
و استدل على مجيء "هل" بمعنى "ما" جحدًا بقول الثـاعر :

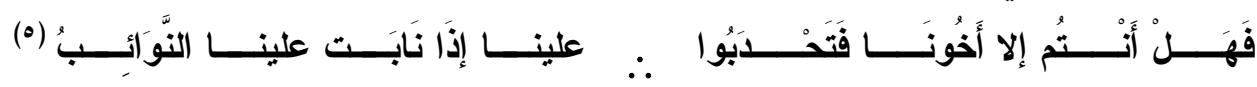
* موقفه من القياس: القياس هو الأصل الثاني من أصول النحو يُفْزَعُ إلِيه ويكون في الصدارة بعد فقد

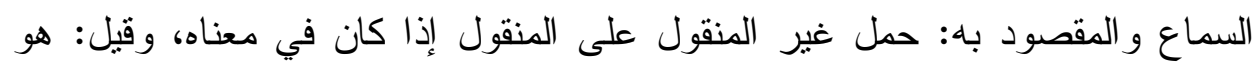

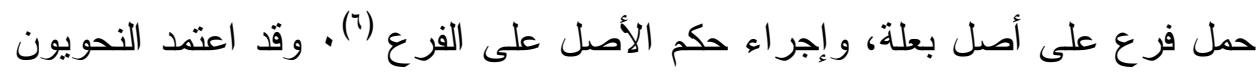
القياس في إثبات قو اعدهم، ووضع القو انين العامة التي تنطبق على الجزئيات المتشابهة وقد استدل ابن خالويه بالقياس - لكن لم يكن كتاب (إعراب ثلاثين سورة) يهتم بالخلافات النحوية -_ـ فقد جاء القياس عنده قليلاً

(

(r)

( السابق (I)

(१^)

(70)

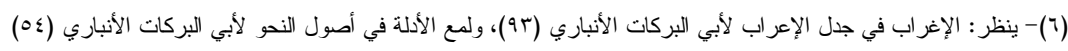


من ذلك حكمه على ألف (اسم) بأنها ألف وصل وقاس ذللك على سقوطها في

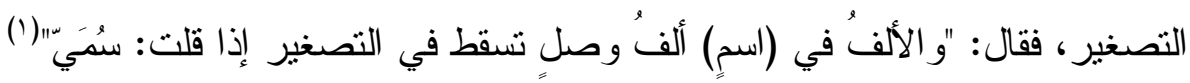

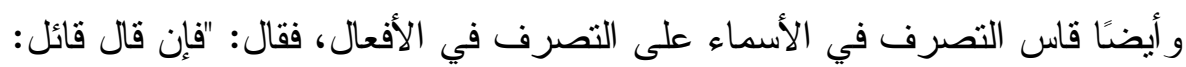

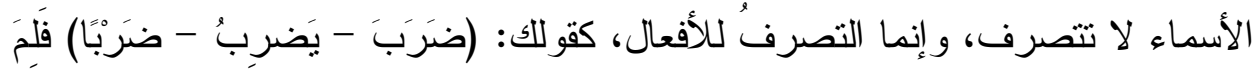

$$
\text { قالت العرب: (بَسنْمَ - يُسَسْمِلُ - بَسْمَلَةً) }
$$

فالجواب في ذلك: أن هذه الأسماءَ مشتقة من الأفعال، فصارت "الباء" لأي: الباء من

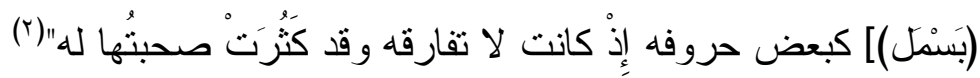

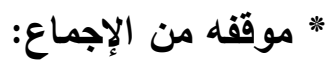

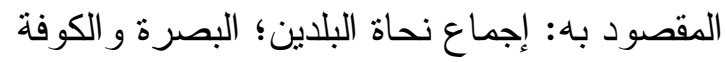

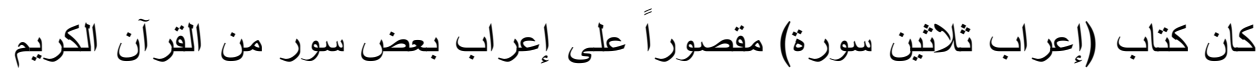
فلم يُعْنَ ابن خالويه بالإجماع عناية كبيرة إلا في مو اطن قليلة جدًا.

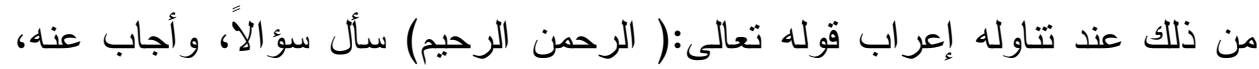

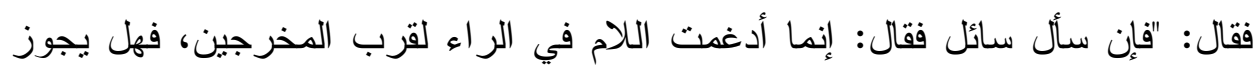

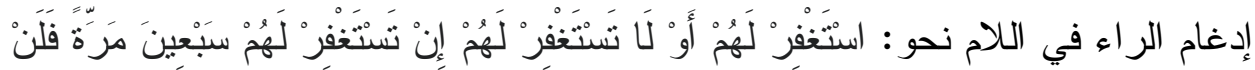

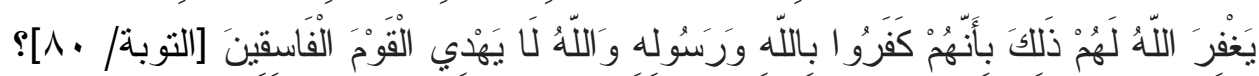

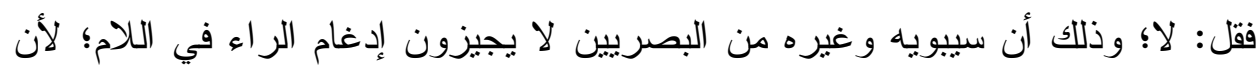

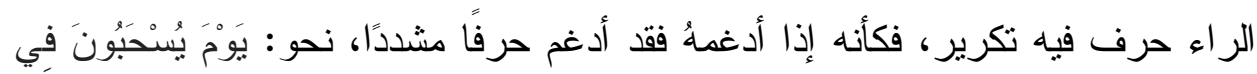

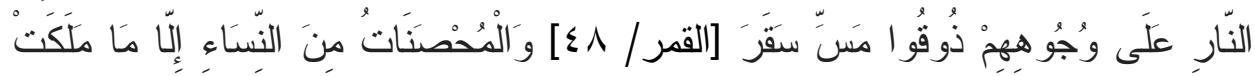

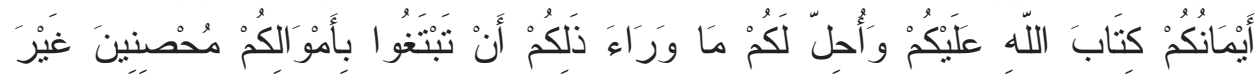

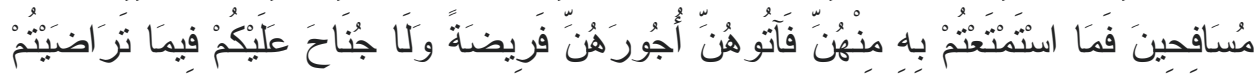

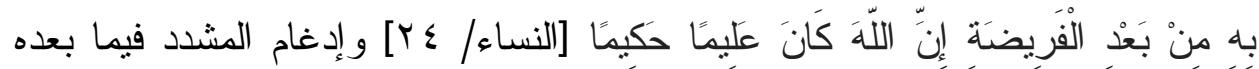

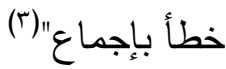

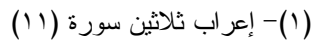

(Y)

(r) 
الخاتمة:

الحمد لله الذي هدانا لهذا وما كنا لنهندي لولا أن هدانا الله، والصلاة و السلام على

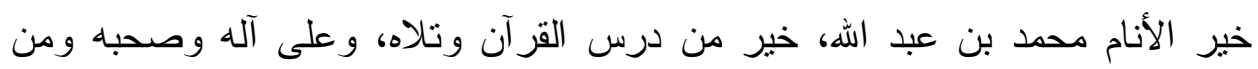
اهتدى بهداه

وبعد هذه الرحلة العلمية الثائقة مع هذا العالم الجليل 》ابن خالويهه من خلال دراسة النحو الكوفي في كتابه 》إعر اب ثلاثين سورة) فقد أسفرت هذه الدر اسة عن نتائج عدة، منها: 1- أثبت البحث بالدليل القاطع أنه من نحوي المدرسة البغدادية المتأخرين، حيث جمع بين آراء نحويي البصرة و الكوفة، و اعتمد مصطلحاتهما.

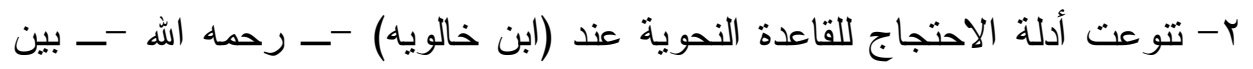
الاعتماد على السماع، أو القياس، أو عليهما معًا، كما اعتمد كذللك على الإجماع.

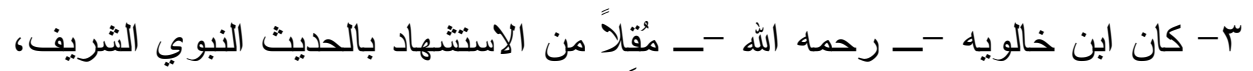
سو اء في تقرير القو اعد أم في الانتصار لآرائه.

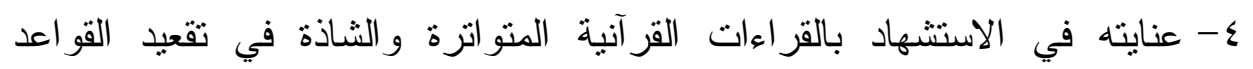
النحوية، فكلها كلام الله تعالى، لا مدخل للبشر فيها. ه- عنايته في الإكثار من الاستدلال بالشعر العربي سواء أكان ذلاك الاستدلال لحكم نحوي، أو فنايته لبيان معنى لغوي.

ج- اتكأ كثير ا على كلام العرب، و أوغل في عرض أوحه تصرفهم في الكلام بما يجعله استدلالا على ما يورده. - V اتضحت ثقافة ابن خالويه اللغوية، وسعة معرفته بلغة العرب، وتبحره في معرفة

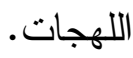
^- يميل ابن خالويه إلى الاختصسار حينا، وإلى التوسع والاستتار حينا آخر، ولم أجد ما يمكن رد سبب ذلك إليه. 


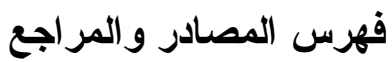

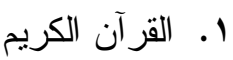

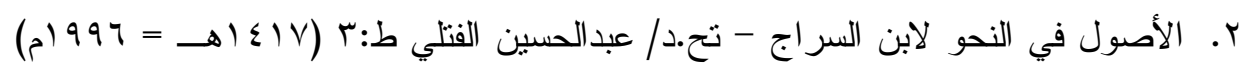

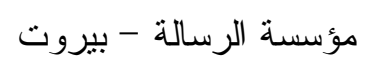

r. إعر اب ثلاثثن سورة من القر آن الكريم ـ ابن خالويه ـ مكتبة المتنبي ـ القاهرة

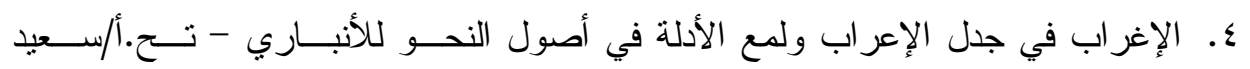

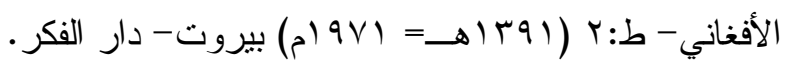

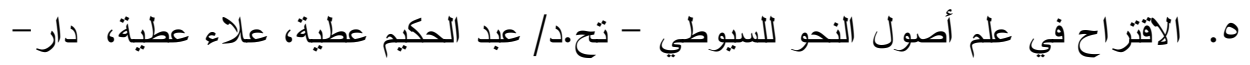

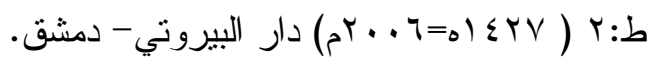

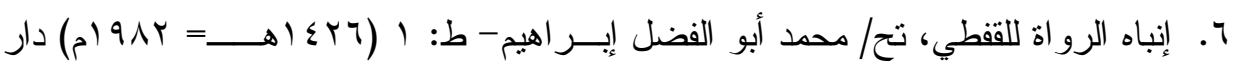
الفكر العربي - القاهرة، مؤسسة الكتب الثقافية- بيروت.

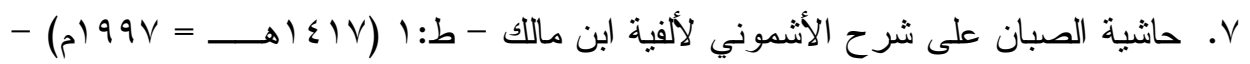

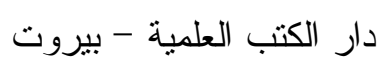

^. سنن التزمذي ت/ محمود محمد محمد حسن نصار - طا دار الكتب العلمية 9. شذرات الذهب في أخبار من ذهب - لابن العماد الحنبلي - تح/عبد القادر الأرنساؤوط،

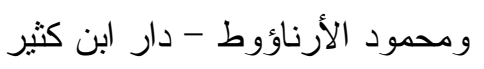

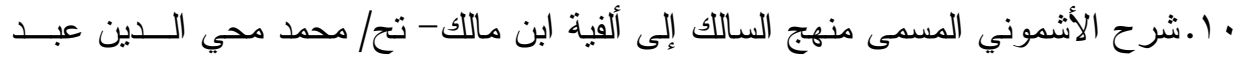

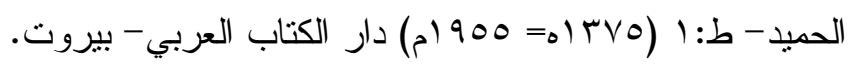

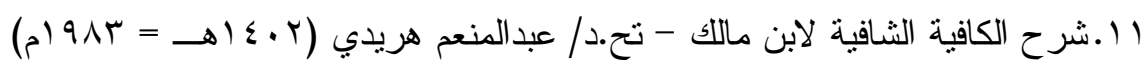

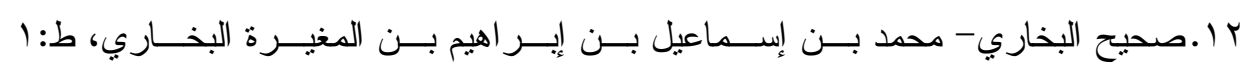

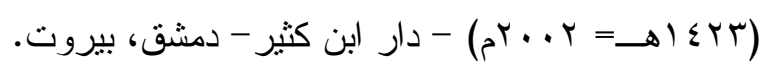

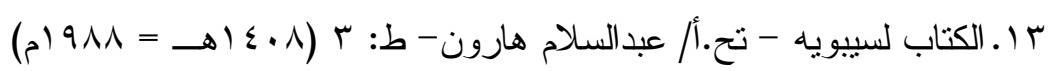

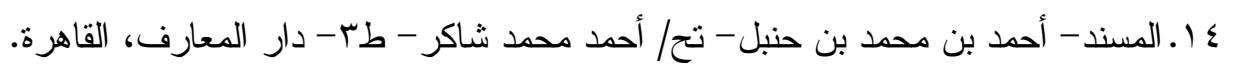

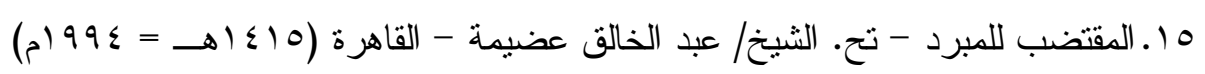

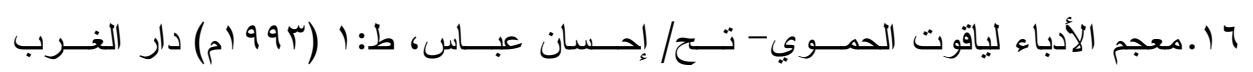

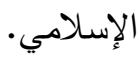




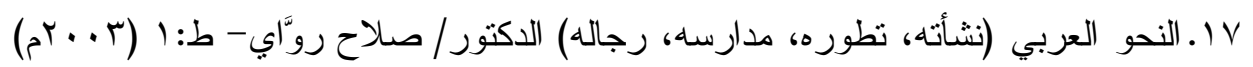
دار غريب للطباعة و النشر - القاهرة

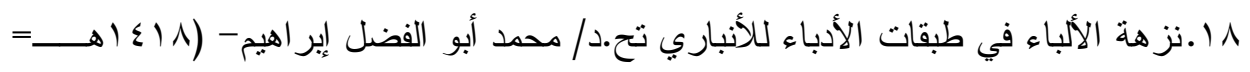

$$
\text { 1991 ام) دار الفكر العربي- القاهرة }
$$

9 1.نشأة النحو وتاريخ أثشهر النحاة/ الثيخ محمد الطنطاوي، ط:ب (990 (م ) دار المعارف،

$$
\text { القاهرة. }
$$

• r.وفيات الأعيان لابن خلكان -- تح.د/ إحسان عباس -_ دار صادر - بيروت 